can be used directly as pulverised boiler fuel. After various technical difficulties had been overcome, it came to be realised that the gas should be utilised for town gas supply in order to give the process a chance of economic success-the gas being the most valuable product. This has necessitated embarking upon further modifications of the process so as to obtain a gas rich enough for distribution. This last stage in the development of the process is now in process of development.

The two British workers described the 'Babcock' process, which has been the subject of experiment for ten years at the Dunstan station of the Newcastle Electric Supply Co. In this case a Northumberland coal slack is subjected to heat by direct contact of a mixture of superheated steam and combustion products on its way to the grate of a stoker. As this plant is now in its third year of operation, no doubt is felt as to its practicability, and designs have been prepared for a unit capable of dealing with 160 tons of coal per day, which will be commensurate with modern boiler practice. From 1 ton of coal costing $11 s$. it is said that by-products valued at $8 s .11 \mathrm{~d}$. are obtained, and considerable optimism is displayed as to the future of the combination.

In this respect, these opinions are scarcely in accord with those of Rosin and McEwen. The former expresses the exact converse, while the latter regards the evaluation of the gas as a key to financial success. It may be remembered that the existing producers at the moment find coal tar oils an embarrassing drug on the market. It will therefore be wise to suspend judgment as to the future of precarbonisation of boiler fuel. No appreciable reduction, if any, of the cost of generation, is to be anticipated. There would be a gain in the abolition of smoke by the power station and better conservation of the chemical values of the coal.

H. J. H.

\title{
Work of the Canadian School of Prehistory in France in 1929.
}

HOR four months, July to October inclusive, the Canadian School of Prehistory has been carrying on excavations in the classic hillside of CombeCapelle, in the beautiful valley of the Couze-a tributary of the Dordogne, in which many gisements occur. It was there that some twenty years ago Homo Aurignaciensis hauseri, Klaatsch, was found. Mousterian, Aurignacian, and Solutrean materials, implements, engravings, etc., have also been found there, whilst a certain terrasse below the Plateau Ruffet appears to contain so many typical Acheulean hand-axes-coups de poing-that an Acheulean horizon seems indicated.

This is the fourth year of work by the Canadian School at Combe-Capelle, and one main fouille has yielded very interesting and practically unique types of tools of flint deserving special notice. Four collections of the very best found during this year's explorations were prepared for (1) The Musée national des Eyzies, Dordogne, headquarters of the School; (2) St. Germain-en-Laye; (3) Institut de Paléontologie Humaine ; and (4) Le Musée Cartailhac, Université de Toulouse, Haute-Garonne.

Besides these collections, which were labelled carefully as to precise geological strata from which they came, from Beds No. I., No. II., No. III., No. IV., occurring at Combe-Capelle, of which some twentyfive cases were shipped to Canada after inspection by the Beaux-Arts of Paris, other series were obtained from (I) Le Moustier (Upper Cave), and from the Émile Bompson property near the classic abri of that name. Four district beds, older than the oldest Mousterian known at Le Moustier Abri up to last year, were searched, and valuable and new information gathered of prehistoric value.

By request, the Canadian School was engaged in two other sites during 1929, namely, at Gavaudun, la Grotte du Moulin du Milieu, Lot-et-Garonne, where new facts were recorded of geological, palæontological, and archæological significance; (2) at Le Ruth, in the Vézère Valley, close to some old Mousterian atelier, which yielded some typical Mousterian implements besides teeth and bones of reindeer, lion, great stag, bison, horse, and claw of an eagle.

The School also visited an Azilian-Tardenoisian site near Sauveterre Lalémance (Lot), where a phase of these two periods seems to give some foundation to $M$. Coulonges, digging there, in establishing a sauveterrian phase of the uppermost palæolithic of that region. Geometrical pieces, microliths in large numbers, occur, associated with an abundant fauna, all of which will no doubt soon be described. The caves, rock shelters, and museums of the Dordogne or Périgord District were visited by the director and students of the (Canadian) School of Prehistory, every facility being afforded by M. Peyrony, administrator of the Beaux-Arts, to study the paintings, drawings, sculptures, engravings, and industries of the different ages represented in that remarkable locality. Les Eyzies is the European headquarters of the School, and a few days were spent by some members of the School in the Ariège Caves, in the Grimaldi Caves of Italy, and in the Museums of Natural History in Toulouse and Marseilles, where excellent collections in prehistory are housed to advantage.

The School's record of finds in France, Italy, England, and Holland have enabled it during 1929 to furnish the University of Toronto, that of Alberta (Edmonton), of Saskatchewan (Saskatoon), and of Manitoba (Winnipeg) with systematic series covering most of the periods in prehistory of the old and of the new Stone Age. The headquarters of the School in Canada is in Ottawa, Laboratory of Geology and Palæontology, Elgin Annex, where the director of the School has his office.

\section{The Biblical Manna. ${ }^{1}$}

THERE has always existed among scientific workers a wide divergence of opinion as to the true nature and origin of the manna, believed to have fallen from heaven to provide food for the Israelites in the Sinai desert during the Exodus from Egypt. Some authors considered the manna to be a desert lichen, Lecanora esculenta Nees, while others connected it with desert shrubs of the genus Tamarix and considered it to be either a physiological secretion of the plant, or its sap flowing from the wounds caused by insects. In order to solve this problem, the Hebrew University in Jerusalem organised in 1927 a small expedition to the Sinai Peninsula, and the leaders of that expedition, Dr. F. S. Bodenheimer and Dr. O. Theodor, have just published a very interesting account of their investigations.

The expedition visited some classical localities where manna was recorded. In the course of investigations, ${ }^{1}$ Ergebnisse der Sinai-Expedition 1927 der Hebraischen Universität,
Jernsalem. Pp. 143+24 tafeln. (Leipzig: J. C. Hinrichs'sche Buchhernsalem. Pp. 
it was established beyond doubt that the appearance of manna is a phenomenon well known in other countries under the name of 'honey-dew', which is a sweet excretion of plant-lice (Aphidæ) and scaleinsects (Coccidæ). Two scale insects mainly responsible for the production of manna were found, namely, Trabutina mannipara, Ehrenb., occurring in the lowlands, and Najacoccus serpentinus var. minor Green, which replaces the former in the mountains. Two other Hemipterous insects, Euscelis decoratus Haupt and Opsius jucundus Leth., also produce manna, but to a lesser extent. All these insects live on Tamarix nilotica var. mannifera Ehrenb. ; no manna was observed on other species of Tamarix, a fact probably due to some physiological peculiarities of the former. The authors observed the actual excretion by the insects of drops of clear sweet fluid, and proved by experiments that the fluid is ingested by the insects from the vessels of the phloem. When in an experiment a twig bearing the insects was placed in water, and the bark was cut below the insects, the production of manna continued in a normal manner, but it stopped as soon as the flow of carbohydrate solution from the leaves was interrupted by cutting off the bark above the insects. The dry desert climate of Sinai causes the syrup-like fluid excretion to crystallise, and the whitish grains thus produced, which cover the branches or fall to the ground underneath them, constitute the true manna of the Bible.

A chemical analysis of the manna demonstrated the presence of cane sugar, glucose, fructose, and saccharose; pectines were also found, but there was no trace of proteins.

Detailed deseriptions of the manna insects are given in the report, which includes very good photographs of various stages of the production of the manna. Notes on the course of the expedition and on the fauna of the Peninsula of Sinai in general provide very interesting reading on that still practically unexplored country.

\section{Fauna of the Batu Caves.}

THE Batu Caves, near Selangor, were discovered in 1879 , and the general character of the caves and their fauna was made known in 1898 by $H$. $N$. Ridley, and subsequent faunal records were made by Annandale and others. Mr. and Mrs. Cedric Dover have recently explored the caves, the total length of which is about 2500 feet, and their collection is the subject of a series of papers in the Journal of the Federated Malay States Museums (vol. 14, 1929).

The animals now reported upon include Mollusca, Crustacea, Nematoda (a new species of Dorylaimus), Arachnida, and seven orders of insects. Of the four molluses, all gastropods, the genus Opeas was common throughout the cave, especially on damp boulders and on the walls, and both the species found (described as new) have eyes in which the pigment is small in amount or absent. Two isopod Crustacea are recorded-Armadillo intermixtus and Philoscia dobakholi - the latter, first described in 1924 from the Siju Cave in Assam, has "somewhat imperfect" eyes and a light colour.

The late G. O. Sars has given a detailed description of a new species of Parabathynella taken from a small pool about 900 feet from the entrance to the cave. These examples have seven pairs of well-developed legs and a rudimentary eighth pair, as contrasted with only five pairs of legs in the European specimens of $P$. stygia in which the three posterior trunk segments have no limbs-probably owing to their immature condition. Prof. Sars did not accept Dr. Calman's view that the Bathynellacea are Syncarida; he placed them in the division Anomostraca of the Malacostraca, and regarded them as "very primitive forms, apparently constituting the still living remains of an antediluvian fauna". Their primitive characters include the uniform segmentation of the body, the sharp definition of the first segment of the trunk, and their primitive limbs, and it is suggested that the Bathynellacea are the predecessors of the Amphipoda.

The Arachnida include a Pedipalp, spiders of four genera, and a new species of the tick Ornithodorus. Among the insects recorded are two genera of blattids, a strongly pigmented new species of Gryllotalpa (the first mole-cricket to be found in a cave), an earwig, a Myrmeleonid, and five species of Microlepidoptera, one of which, a Tinea, is common in the cave and its larvæ are abundant in the bat guano. Of the ten species of Diptera collected, none shows any modifications for cave life. Two Reduviid bugs are recorded and a dozen beetles-none markedly modified for a cavernicolous habit. The discovery of many larvæ of beetles in the cave indicates that some at least of these beetles have found congenial conditions and are firmly established there.

\section{University and Educational Intelligence.}

LoNDoN.- The title of emeritus professor has been conferred on Dr. E. A. Gardner on his retirement from the Yates chair of archæology at University College, and on Dr. F. W. Oliver on his retirement from the Quain chair of botany at University College.

The following doctorates have been conferred: D.Sc. in chemistry on Mr. J. Bardhan (Imperial College - Royal College of Science), for a thesis entitled " I. The Chemistry of Balbiano's Acid; II. The Action of Cyanoacetamide with $\beta$-diketones "; Mr. K. Krishnamurti (University College), for a thesis entitled "Investigations on the Scattering of Light in Colloidal Solutions and Gels"; Mr. F. G. Mann (Battersea Polytechnic), for a thesis entitled "The Complex Metallic Salts of the Aliphatic Polyamines". D.Sc. in zoology on Mr. William Rowan (University College), for a thesis entitled " Experiments in Migration, including an Investigation of the Sexual Rhythm and Histology of the Gonads in Birds". D.Sc. in geography on Miss E. G. R. Taylor, for a thesis entitled "Studies in Tudor Geography, 1500-1583".

Portsmouth Municipal College sends us a booklet issued on the occasion of the visit of H.R.H. Prince Arthur of Connaught on Dec. 9 in connexion with an exhibition commemorating the twenty-first anniversary of the opening if the college. Erected, equipped, and maintained by the Portsmouth City Education Authority, it serves the higher educational needs of a wide area surrounding the city, including the Isle of Wight and parts of Hampshire and West Sussex, whence come twenty per cent of the technical college students. It comprises departments of science, arts, technology (mechanical, civil, electrical, marine, motor, and other branches of engineering, building trades and pharmacy), commerce and domestic science, and, in addition, a school of art and a training college, affiliated to the University of Reading, for women teachers. It has thus, as pointed out in a foreword by the chairman of the governing body, the potential constituents of a university college. The work includes, on the technical college side, full-time academic courses leading to degrees of the University of London in arts, pure science, engineering, etc., and, more recently, in pharmacy and a wide range of other courses both full-time and part-time. The number of full-time students in this part of the College has increased from 66 to 507 . The number of training college students has increased from 180 to 215 .

No. 3139, VoL. 124] 